\title{
THE PROCESS OF COOPETITIVE STRATEGY: A CASE STUDY OF MICROBREWERIES IN PORTO ALEGRE
}

\author{
JEFFERSON M. MONTICELLI ${ }^{1}$ \\ (iD) https://orcid.org/0000-0002-1605-7090 \\ ALEXANDRE B. DA SILVEIRA ${ }^{2}$ \\ (iD) https://orcid.org/0000-0002-5620-2125 \\ LUCIANA M. DA SILVA ${ }^{3}$ \\ (iD) https://orcid.org/0000-0003-1670-0629
}

To cite this paper: Monticelli, J. M., Silveira, A. B. da, \& Silva, L. M. da. (2018). The process of competitive strategy: A case study of microbreweries in Porto Alegre. Revista de Administração Mackenzie, 19(4). doi:10.1590/1678-6971/eRAMR180012

Submission: Jan. 31, 2018. Acceptance: Apr. 26, 2018.

1 Centro Universitário La Salle (Unilasalle), Canoas, RS, Brazil.

2 Centro Universitário Ritter dos Reis (UniRitter), Porto Alegre, RS, Brazil.

3 Universidade do Vale do Rio dos Sinos (Unisinos), São Leopoldo, RS, Brazil.

\footnotetext{
(cc) BY 


\section{ABSTRACT}

Purpose: The study presents a dynamic and complex procedural experience performed by small microbreweries in a cluster in Porto Alegre, Brazil. Thus, this article aims to establish theoretical propositions about coopetition strategies in this context.

Originality/value: One of the gaps in the organizational studies is an understanding of how the process of developing a new strategic dynamic takes place. We consider coopetition to be a process that involves narrow strategies of simultaneous coopetition and cooperation between competing firms, in different areas and levels of interaction.

Design/methodology/approach: Qualitative, exploratory research was conducted, using data triangulation and multiple methods. The case study technique was adopted to perform an in-depth examination of the phenomenon of secondary data collection, participant observations, and semi-structured interviews.

Findings: The results showed that microbreweries are developing a strategic process of coopetition through greater sharing of resources, information, interactions, learning, and inter-organizational and intra-organizational knowledge, essentially in the stages of distribution and sales. The reports and evidence of the research showed synergy between the mechanisms and common goals found, thus demonstrating the dynamic of these small businesses.

\section{KEYWORDS}

Coopetition. Strategy. Learning. Processes. Microbrewery. 


\section{INTRODUCTION}

The growing demand in the markets linked to social, economic and cultural changes is changing the current paradigms of the production, distribution, and supply of products and services, leading organizations to shape their businesses to search for greater coopetitive advantages. These coopetitive demands introduce different levels of sophistication and differentiation associated with low costs, innovation, adaptation and quick response, which not all structured organizations can conservatively achieve (Brandenburger \& Nalebuff, 1995).

This new dynamic — called coopetition-is evidenced and interpreted by cooperation associated with market coopetition in pursuit of a common goal, which is influenced by the searches and behaviors of the consumer, who are increasingly looking for product innovations and differentiation (Bengtsson \& Kock, 2014). This study is guided by the definition of market-oriented coopetition as "a paradoxical relationship between two or more actors simultaneously involved in horizontal coopetitive interactions and vertical or horizontal cooperative interactions regarding activities that are close to the market" (Chiambaretto, Le Roy, Mira, \& Robert, 2018, p. 575). Therefore, coopetition and cooperation go hand in hand in any situation, and when the two are working together, a coopetition strategy emerges among firms in search of common results (Bengtsson \& Kock, 2014).

The nature of these strategies is paradoxical, but when applied simultaneously, they can contribute to the development and outcome of competitive advantages through interactions that can complement, integrate, share, and generate knowledge and learning for organizations (Padula \& Dagnino, 2007; Raza-Ullah, Bengtsson, \& Kock, 2014). Dahl (2014) expanded this concept and proposed a dynamic process in the strategy that can change the goals and purposes of the development of coopetition.

In this context, the Brazilian microbrewery market has gone through a significant transformation with fierce coopetition and expansion because of the large demand for differentiated and premium products (Stefenon, 2012). Although this market is characterized by the concentration and market share of a few firms, in recent years, the emergence of new small business competitors has significantly changed the product supply and distribution in the domestic market. These productive clusters show distinctive behaviors in the relationships of cooperation and coopetition when compared to some consolidated players in the domestic beer market (Stefenon, 2012). 
Following this perspective, there has been a movement and grouping of small firms producing specialty beers located in the Anchieta neighborhood in the city of Porto Alegre, Brazil, since the beginning of the decade. Initially, there were five firms, although today, the number has grown to nine firms, representing $21 \%$ of the microbreweries in Rio Grande do Sul, a state in the South of Brazil. These breweries hold a representative share of the market compared to the national breweries (Serviço Brasileiro de Apoio às Micro e Pequenas Empresas [Sebrae], 2017).

Considering this context, the following research question is proposed: how do the development processes of the competitive strategy occur among the microbreweries in the city of Porto Alegre? Thus, this article aims to establish theoretical propositions about coopetition strategies based on the cluster of microbreweries in Porto Alegre. By answering this question, this study proposes that it has made three contributions. First, this article contributes to the coopetition topic by creating theoretical propositions through in-depth and explanatory case studies (e.g., Chiambaretto, 2015). We aim to further this emerging theoretical field by understanding the empirical use of competitive strategies (e.g., Bengtsson, Kock, Lundgren-Henriksson, \& Näsholm, 2016; Bengtsson \& Razah-Ullah, 2016). In this sense, we applied Dahl's (2014) framework, which applies shared interactions to the dynamics of coopetition.

Second, the research presents a better understanding of the organizational phenomena that are re-shaping the traditional and formal propositions on the development of business strategies. Despite the numerous studies related to coopetition, the concept is still considered to be a theory in progress, which uses multiple definitions, lacks generalization, and has a limited context (Bengtsson \& Kock, 2014; Bouncken, Gast, Kraus, \& Bogers, 2015).

Third, the study presents a dynamic and complex process experience performed by these small businesses, which are re-shaping the regional economy through strategies based on coopetition. The searches are limited in terms of exploring a wider range of firms, especially small and medium-sized enterprises (SMEs), startups, and family businesses (Bouncken et al., 2015), because the previous studies have been directed to large firms (Bengtsson \& Johansson, 2012; Bengtsson \& Kock, 2014). However, it is important to analyze SMEs, given the importance of these firms for the networks (Gnyawali \& Park, 2009).

This study continues with the presentation of the main theoretical concepts that form the basis of the research, followed by the description of the methodology. Next, the results of the empirical research and, finally, the 
final considerations, including the contributions, limitations, and opportunities for future studies, are presented.

\section{COOPETITION STRATEGIES}

Coopetition is analyzed by two approaches: as a context and as a process (Bengtsson, Eriksson, \& Wincent, 2010). As a context, coopetition is broadly presented in a chain that adds value to a company through environmental interactions (Brandenburger \& Nalebuff, 1996; Lado, Boyd, \& Hanlon, 1997). This chain refers to customers, suppliers, substitutes, and complementors called "The Value Net". In this relationship, coopetition occurs between the firm and these parts, in any direction, based on the game theory (Nash, 1950). In this case, we can draw an analogy to the market using a pie. The players cooperate to increase the market by creating value and developing the market as if they were going to bake a pie. Then, they compete to capture value in the market, that is, to get the largest piece of the pie (Brandenburger \& Nalebuff, 1996; Gnyawali, He, \& Madhavan, 2006). The interaction of competitive and cooperative strategies will create a syncretic rent or higher overall rent for a firm (Lado et al., 1997). In these terms, coopetition is a relationship strategy wherein the partners mainly the suppliers, firms, and customers-aim to increase the value of their businesses more than it could be obtained individually. The crucial point is to divide the results that the firms obtained through a competitive strategy.

On the other hand, as a process - which is the focus of our researchcoopetition involves narrow strategies of coopetition and cooperation simultaneously between competing firms, in different areas and levels of interaction (Bengtsson \& Kock, 1999, 2000). One continuum ranges from complete coopetition to complete cooperation with different degrees of competitive relations. The stronger the cooperation is, the weaker the coopetition is, and vice-versa (Bengtsson \& Kock, 2000). Two-continuum approaches suggest that different levels of cooperation and coopetition can co-exist in parallel within a competitive relationship, based on a multifaceted concept (Bengtsson et al., 2010).

More recently, coopetition has been considered as a paradoxical relationship between two or more actors simultaneously involved in a cooperative and coopetitive interaction, whether they are horizontal or vertical (Bengtsson \& Kock, 2014). Rarely, it is a stable relational state marked by constant strategic movements of cooperation and coopetition 
(Bengtsson et al., 2010; Roy \& Yami, 2009). It is understood that competition is a form of competing firms that work together to seek common goals that they could not achieve individually.

This perspective, argued by Bengtsson and Kock (2014), is advantageous in considering several views and strategic actions for organizations and their businesses: first, for being a relatively new approach, in which the organizations can find new opportunities; second, for generating less resistance between the competitors and making them allies in its implementation; and third, because the win-win strategies do not lead the other competitors to retaliate, creating a more sustainable game. This proposal aims to stimulate the competitors to think in both directions, i.e., competitively and cooperatively, with the objective of generating a more beneficial strategy and with an unharmful common objective.

In addition, coopetition can change over time by triggers such as changes in the industry or in the institutional environment (Bengtsson \& Kock, 2000; Dahl, 2014; Mariani, 2007). Institutions influence firms' entry into markets (Peng, Wang, \& Jiang, 2008). Consequently, industry or institutional changes are produced by process of the dynamic development of the strategy. But how can they re-create these developments and objectives of the organizations? For Dahl (2014), a reformulation of the development of the goals or purposes of the competitive rules occurs through the interactions between the competitors.

The development of the strategic process can occur for four reasons (Figure 2.1): the process of inter-organizational learning, with the accumulation of trust between competitors; the intra-organizational learning through exchanges with other competitors; changes in the external environment; and successful or unsuccessful results from previous experiences (Dahl, 2014). In addition, according to Lundgren-Henriksson and Kock (2016), the changes and development of coopetition strategy occur at the same levels for which Dahl (2014) argues: intra-organizational, inter-organizational, or about the external environment.

The propositions of Dahl (2014) are described in Figure 2.1: 


\section{(Figure 2.1)}

\section{FRAMEWORK}

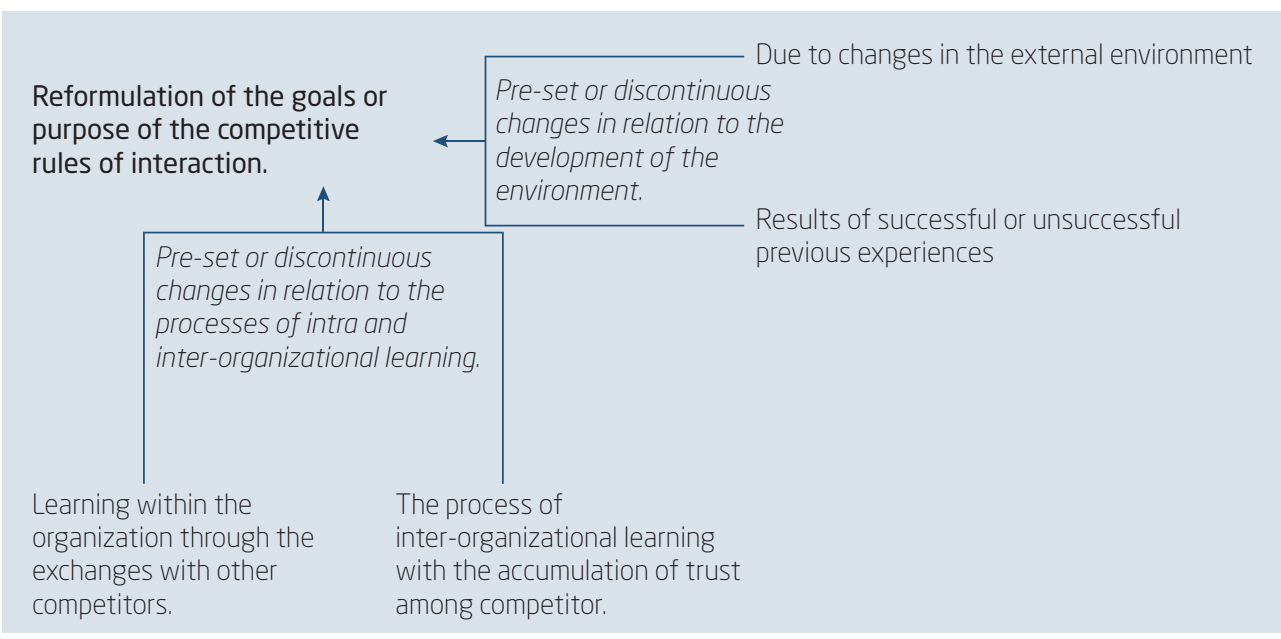

Source: Adapted from Dahl (2014).

The process of inter-organizational learning occurs through learning when there is an increase of trust resulting from actions of goodwill among the competitors (Dahl, 2014). Coopetition is based on trust, reciprocity, and altruism (Kanter, 1994). However, the participants cooperate in different areas than those in which they compete (Luo, 2005), usually collaborating to create value that is distant from the customers and competing to dispute that same value closer to the customers (Bengtsson \& Kock, 2000; Brandenburger \& Nalebuff, 1996; Chiambaretto, Gurău, \& Le Roy, 2016). Intra-organizational learning occurs because of exchanges with competitors using interactions (Dahl, 2014), which enhance performance (Huang \& Chu, 2015; Robert et al., 2017) and absorbent capacity (Luo, Slotegraaf, \& Pan, 2006). There is still the development resulting from external changes, which occurs through changes in the external environment, or because of successful or unsuccessful results from current or previous inter-organizational interactions.

Tidström and Rajala (2016) argued that the development and changes in goals and objectives could occur based on more than one motivation at a time, thus changing the competitive process. Also, the events that generate the changes tend to have participants external to the firms that are competing (Tidstrom \& Hagberg-Andersson, 2012). In this case, it is defined as a progression of changes that designs the balance and the force between the cooperative and competitive interactions (Dahl, 2014). 
More recently, some authors also have observed coopetition as a dynamic and strategic process in which economic actors create value through cooperative interactions and, at the same time, compete to capture part of that same value (Bouncken et al., 2015). In this case, there is a paradoxical combination of cooperation and coopetition and, consequently, their advantages and risks (Chen, 2008). Due to the objectives, market conditions, and continuous evolution of the roles of the actors, this relationship is also dynamic (Hung \& Chang, 2012; Luo, 2007). In this case, changes in the environment can weaken or stimulate divergent behaviours and generate answers for the strategies of the firms in a way that affect the strategies and create the so-called coopetitive advantage (Padula \& Dagnino, 2007). In addition, coopetition could be strengthened by the existence of market commonalities and resource asymmetries. Market commonalities contribute more to coopetition, while resource asymmetries contribute to cooperation (Hung \& Chang, 2012).

\section{DRIVERS OF COOPETITION}

There are different drivers or causes for coopetition between the players. First, common strategic goals are an important antecedent for coopetition. The incentive for coopetition among firms is appropriate to deal with challenges that they cannot face by themselves, such as sharing the investments or risks associated with the business (Choi, Garcia, \& Friedrich, 2010). Therefore, a commitment is a key factor in promoting confidence and in enhancing an ongoing strategic business relationship (Zineldin, 2004), thus allowing synergic behavior.

Second, considering that coopetition requires mutual benefits to establish a relationship, one partner should have certain skills or resources that the other partner needs (Choi, 2005). The heterogeneity of resources can contribute to the formation of competitive relationships because unique and complementary resources can be attractive for coopetition (Dussauge, Garrete, \& Mitchell, 2000). Due to intra-industry complementarities, coopetition allows firms to access complementary resources from external partners (Bengtsson \& Kock, 1999, 2000; Gnyawali et al., 2006; Gnyawali, He, \& Madhavan, 2008). Therefore, firms must trust each other by sharing information and knowledge, but must not forget that they are still rivals. In short, both players must negotiate part of their knowledge with the other player, while buying and selling to compete, eventually. This means having a strategy that allows them to share without (really) sharing (Baumard, 2008). 
Third, competitors expect to reap collective results that are better than the individual results (Brandenburger \& Nalebuff, 1995) through the growth of the market size, creation of a new market, increased efficiency of resource utilization, or improved competitive position (Ritala, 2012). Other expected results cost reduction, risks sharing, scale economies, acceleration of R\&D activities, diversification of the portfolio of products or services, and maintenance of a high level of consumer satisfaction (Luo, 2007; Gnyawali \& Park, 2009, 2011; Ritala \& Hurmelinna-Laukkanen, 2009; Zineldin, 2004).

Fourth, coopetition can be motivated by network externalities in an industry (Bengtsson \& Kock, 1999, 2000). Coopeting firms are integrated into a social structure that allows for inter-firm collaborations (Pellegrin-Boucher, Le Roy, \& Gurău, 2013). Information and social exchange are key factors for initiating coopetition (Bengtsson \& Kock, 2000). Firms that occupy a more central and autonomous position in the network assume greater coopetitiveness among the other agents due to strategic flexibility. Firms with a greater diversity of markets are more likely to obtain results from their centrality and their coopetitive relationship (Gnyawali et al., 2006). In this relationship, three types of resources circulate; i.e., reputation, information, and assets; which are optimized following the firm's position (Gnyawali \& Madhavan, 2001). In these terms, network externalities may increase the potential value creation when firms are participating in coopetition-sharing knowledge. However, not all industries will generate these positive results, particularly low-tech industries with less innovative potential (Ritala \& Hurmelinna-Laukkanen, 2009).

\section{OUTCOMES OF COOPETITION}

Coopetition allows firms to access resources and markets, economies of scale and scope, increased bargaining power, reduction of transaction costs, periods of product development and innovation, and contractual mechanisms to neutralize opportunistic risks. Nevertheless, strategic options enable the assumption of flexible postures (Lado et al., 1997). However, although coopetition is based on convergent interests, its model is criticised for posing risks stemming from opportunism and environmental dynamism (Gulati, Nohria, \& Zaheer, 2000; Hamel, 1991). Therefore, coopetition is not a dichotomous construct on a continuum between competition and cooperation. It is a multidimensional, complex, and dynamic concept that takes different forms and requires multiple levels of analysis about its 
structure, processes, and standards through orthogonal constructs (Padula \& Dagnino, 2007). Coopetition implies shared goals that induce agents to cooperate and compete to reduce risks, losses, and uncertainties, expand their strategic options, and leverage their earnings and performance, but it can also have drawbacks (Le Roy, Fernandez, \& Chiambaretto, 2017).

Coopetition can increase absorptive capacity, enhance information exchange (Ritala \& Hurmelinna-Laukkanen, 2013), and generate more creative ideas than coopetition or cooperation (Zhao, Renard, Elmoukhliss, $\&$ Balague, 2016). However, excessive coopetition can have a negative influence on innovation performance because of concerns about opportunistic behavior (Gnyawali \& Park, 2009; Sun, Wu, Liu, Peng, Zhu, \& Liang, 2012). This happens due to the threat of expropriation because there is a difference between the knowledge created through cooperation and the knowledge appropriated by the coopetition. Depending on the absorptive capacity of the competing firm, the asymmetry and volume of knowledge leakage may be significant (Ritala \& Hurmelinna-Laukkanen, 2009). In addition to the free-riding behavior, another example of the negative externalities of coopetition is the generation of redundant knowledge or learning isomorphism and a reduction in learning efficiency, mainly because as the number of collaborations grows, there is no heterogeneity between the participants (Oliver, 2004). This double-edged sword can be potentiated by the effect of the institutions, particularly in emerging markets.

\section{METHOD}

The research strategy chosen for the development of the study was a qualitative, exploratory research study, employing data triangulation and using multiple methods. This strategy is justified because it provides a better view and understanding of the proposed problem. This kind of research aims to explore situations and phenomena based on a few pre-designed ideas while also better defining the problem and developing an approach that is appropriate for situations of uncertainty, such as when the conclusive results differ from the expectations (Malhotra, 2017).

The case study technique was adopted to perform an in-depth examination of the phenomenon, in its natural context, from multiple sources, (individuals, groups, organizations, and information) using more than one type of data collection and analysis (Yin, 2009). The methodological selection is justified by the interest in understanding the individual and 
group experiences of the respondents while seeking to create meaning and more objectively capture results that can overcome the barrier of the uncertainty arising from obtaining information from both sides of the development process of the coopetitive strategy.

We used a pre-existing theoretical framework for the case selection and data collection to answer the research question and to allow the researchers to conduct a more detailed analysis of the case studied. According to Flick (2014), the triangulation of methods is characterized as a key element for exploratory research and emerges as a strategy for a dialogue between several different areas of knowledge that can achieve an understanding of and relationship between theory and practice with the aim of providing multiple views of a single phenomenon. On this line, three different research procedures were carried out with the objective of triangulating the methods to enrich the understanding and knowledge of the phenomenon. First, data collection was carried out with secondary sources, such as the websites of the firms operating in this market in the city of Porto Alegre, news from portals, specialized magazines, and the associations for this market, as defined in Figure 5.1.

(Figure 5.1)

SECONDARY DATA OF RESEARCH

\begin{tabular}{ll}
\multicolumn{1}{c}{ Name of Portal } & Channel or content researched and analyzed \\
\hline $\begin{array}{l}\text { Associação dos Cervejeiros Artesanais do } \\
\text { Rio Grande do Sul (ACervA Gaúcha) } \\
\text { (Association of Artisan Brewers of Rio } \\
\text { Grande do Sul) (ACervA, 2016) }\end{array}$ & History, Mission, Views, and News. \\
\hline $\begin{array}{l}\text { AGM (Associação Gaúcha das } \\
\text { Microcervejarias/Gaucho Association of }\end{array}$ & History, Mission, Views, and News. \\
Microbreweries) (AGM, 2016) & \\
\hline Babel Brewery & History, Mission, Views, and News. \\
\hline Portoalegrense brewery & History, Mission, Views, and News. \\
\hline Seasons Brewery & History, Mission, Views, and News. \\
\hline Artisan Beers of Brazil & $\begin{array}{l}\text { Bairro Anchieta Em Porto Alegre: Você Tem Que } \\
\text { Conhecer. (Anchieta neighborhood in Porto Alegre: } \\
\end{array}$ \\
\hline You Have to See It.) \\
\hline
\end{tabular}




\section{(Figure 5.1 (conclusion))}

\section{SECONDARY DATA OF RESEARCH}

\begin{tabular}{|c|c|}
\hline Name of Portal & Channel or content researched and analyzed \\
\hline Escola da Cerveja (2016) & History, Mission, Views, and News. \\
\hline GI RS & $\begin{array}{l}\text { Com nove cervejarias, bairro de Porto Alegre é polo } \\
\text { para amantes da bebida. (With nine breweries, a } \\
\text { neighborhood in Porto Alegre is a pole for those } \\
\text { who love the drink) }\end{array}$ \\
\hline Irmãos Ferraro Microbrewery & History, Mission, Views, and News. \\
\hline Beer Art O Portal da Cerveja (2016) & $\begin{array}{l}3^{0} \text { Seminário de Gestão para Microcervejarias } \\
\text { Artesanais, em Porto Alegre (the } 3^{\text {rd }} \text { seminary of } \\
\text { management for artisan microbreweries in Porto } \\
\text { Alegre - Event, free admission, as part of the } \\
\text { actions to stimulate artisan breweries). }\end{array}$ \\
\hline Sebrae (2017) & $\begin{array}{l}\text { Microcervejarias ganham espaço no mercado } \\
\text { nacional. (Microbreweries gain space in the } \\
\text { domestic market) }\end{array}$ \\
\hline Semana da Cerveja (2016) & $\begin{array}{l}\text { Sobre a SemanalExperiência e Negócio (About the } \\
\text { Week\Experience and Business) }\end{array}$ \\
\hline Zero Hora & $\begin{array}{l}\text { Notícia sobre o Polo Cervejeiro e sobre a semana } \\
\text { da cerveja (News about the Brewing Pole and } \\
\text { about the beer week) }\end{array}$ \\
\hline
\end{tabular}

Source: Elaborated by the authors.

Next, exploratory research of the primary sources was conducted with participant observations of two different researchers who participated in the $3^{\circ}$ Seminário de Gestão para Microcervejarias Artesanais, carried out by the Serviço Brasileiro de Apoio às Micro e Pequenas Empresas do Rio Grande do Sul (Sebrae RS). The objective was to detect and to minimize the eventual biases or trends of the individual researchers and to make different perspectives, reflections, and analyses possible. For the data collection, a script for the observations and interviews was developed based on the categories and elements proposed by Dahl (2014).

Given this script, Semi-structured open-ended questions considering the categories of Dahl (2014) and the local reality of the microbreweries were developed. The case study protocol explained the theoretical background, the design of the research, the criteria for case selection, the 
case study procedures, the operationalization of the data collection and analysis, the plan validity, the study limitations, and the schedule. The questions were asked one at a time, with annotations and simultaneous recordings in an informal atmosphere among the participants.

\section{(Figure 5.2)}

INTERVIEW SCRIPT

\begin{tabular}{ll}
\multicolumn{1}{c}{ Category } & \multicolumn{1}{c}{ Topics of Analysis } \\
\hline $\begin{array}{l}\text { The process of inter-organizational } \\
\text { learning, with the accumulation of trust } \\
\text { among competitors. }\end{array}$ & $\begin{array}{l}\text { Proximity; exchange of experiences; conjoint } \\
\text { learning; access to suppliers; supply chain } \\
\text { integration; cost reduction. }\end{array}$ \\
\hline $\begin{array}{ll}\text { Intra-organizational is learning through } \\
\text { exchanges with other competitors. }\end{array}$ & $\begin{array}{l}\text { Information flow; qualification and training of the } \\
\text { management. }\end{array}$ \\
\hline Changes due to the external environment. & $\begin{array}{l}\text { Changes in the relationships; sharings; frequency } \\
\text { of contact; interactions and connections with } \\
\text { other segments; market search. }\end{array}$ \\
\hline Results from successful or unsuccessful & $\begin{array}{l}\text { Conjoint action; integration with other sectors; } \\
\text { previous experiences. }\end{array}$ \\
\hline
\end{tabular}

Source: Elaborated by the authors.

Figure 5.3 presents the location map of the firms belonging to the pole, in addition to their geographical proximity. Initially, nine firms were the target for the research. However, only four of them responded to the invitation to participate in the study. These firms were observed, and their managers were interviewed by phone and in person.

In the third step of the study, four in-depth and semi-structured interviews were conducted, with one being face-to-face and three being by telephone, with the main managers of the pioneer firms of the Brewery Pole of the Anchieta Neighbourhood of the city of Porto Alegre. The goal was to understand the relationships of cooperation and coopetition existing between the other actors in this niche market. Figure 5.4 summarises the approaches and techniques used for the case study. 


\section{(Figure 5.3)}

\section{ADAPTED LOCATION MAP OF THE BREWERIES}

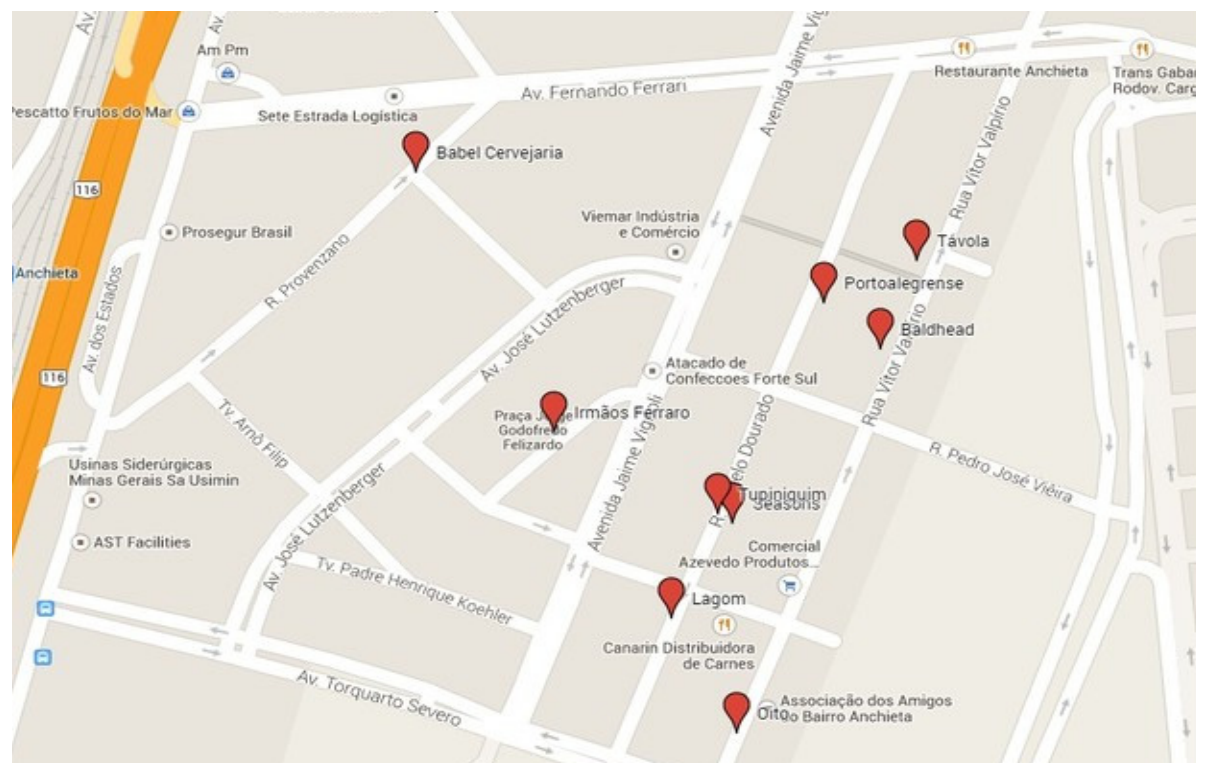

Source: Google Maps (2017).

\section{(Figure 5.4)}

\section{APPROACHES AND TECHNIQUES USED}

\begin{tabular}{llll}
\multicolumn{1}{c}{ Position } & Foundation & \multicolumn{1}{c}{ Firm } & \multicolumn{1}{c}{ Type of approach/Technique } \\
\hline Director/Co-owner. & 2013 & Babel Brewery & $\begin{array}{l}\text { Observations in the event, casual } \\
\text { conversation at the event and } \\
\text { interview by phone. }\end{array}$ \\
\hline Director/Commercial. & 2012 & $\begin{array}{l}\text { Portoalegrense } \\
\text { Bewery }\end{array}$ & $\begin{array}{l}\text { Observations in the event, casual } \\
\text { conversation at the event and face-to- } \\
\text { face interview at the local. }\end{array}$ \\
\hline Director/Owner. & 2010 & $\begin{array}{l}\text { Seasons } \\
\text { Brewery }\end{array}$ & $\begin{array}{l}\text { Observations in the event, casual } \\
\text { conversation at the event and } \\
\text { interview by phone. }\end{array}$ \\
\hline Director/Co-owner & 2009 & $\begin{array}{l}\text { Irmãos Ferraro } \\
\text { Microbrewery }\end{array}$ & $\begin{array}{l}\text { Observations in the event, casual } \\
\text { conversation at the event and } \\
\text { interview by phone. }\end{array}$ \\
\hline
\end{tabular}

Source: Elaborated by the authors. 
Finally, the research employed triangulation techniques in methodological procedures with the aim of seeking to enrich and complement the knowledge and overcome the epistemological potential of the individual methods (Flick, 2014), while associating secondary data, participant observations, and semi-structured interviews. Furthermore, the data triangulation was carried out to enable better distinction, credibility, and validation of the information obtained, which was transcribed and analyzed by the researchers. The combination of different shapes, scales, and analyses enrich and supports the credibility, validity, and quality of research (Flick, 2014). For data analysis purposes, the content analysis technique was used to infer knowledge through the generation or not of quantitative indicators (Bardin, 2011). The data analysis was performed using summaries prepared by the authors, interview recordings, as well as printed and digital materials. The data were constantly compared (Strauss \& Corbin, 1990) between theory and results, with the aim of furthering the discussion on coopetition and the propositions made.

\section{ANALYSIS OF THE RESULTS}

To investigate the dynamics of the development of the coopetitive strategy from the four mechanisms: 1. inter-organizational learning, with the accumulation of trust among competitors; 2 . intra-organizational learning through exchanges with other competitors; 3. external changes; and 4. results from successful or unsuccessful previous experiences, proposed by Dahl (2014), it was necessary to select and observe how this group of organizations has developed through an analysis of the evolution of events and facts in which they were involved.

This case allowed the identification of four mechanisms, as proposed by Dahl (2014), starting with the external changes that were evident in the foundation of Associação dos Cervejeiros Artesanais do Rio Grande do Sul (ACervA) in Rio Grande do Sul, which was born from a thread in an internet portal in 2004 and became a brotherhood. In 2007, it became an association of local agents disseminating the beer culture, with the aim of studying, researching, tasting, and producing a handmade product. Such changes were highlighted by the interviewee of the Seasons Brewery:

We were always engaged in various initiatives together since the Foundation of ACervA and later with the actions that happened mainly due to external expectations of the Group. We had the focus and the goal of searching for markets and then educating the public (consumers) 
and even beer producers from fellowships, lectures, workshops, and events with the participation of all (Representative of the Seasons Brewery, personal interview, 24 Nov. 2016, translated by the author).

The second step, which presents a significant evolution of this process, is associated with inter-organizational learning, with the accumulation of trust generated between the competitors, which seek new integrations and synergies between their supply chains from the interactions with the aim of gathering and providing services, techniques, and exchanges of experiences between those involved in the brewer pole and their followers. In this context, the importance of mutual trust and commitment to achieve common objectives is emphasized (Kanter, 1994). The Escola da Cerveja de Porto Alegre (Beer School of Porto Alegre) was created in 2010 with the idea of promoting the goals mentioned above; in 2012, the Associação Gaúcha de Microcervejarias (AGM, Gaucho Association of Microbreweries) had the purpose of integrating and developing the associativism between the organizations. One of the respondents stressed this event as follows:

AGM is the result of a development work of associative, since 2012 and 2013, started by a small group of breweries in the Anchieta neighborhood, in Porto Alegre, and which has also culminated in the formation of the Brewer Pole project of SEBRAE RS (Representative of the Babel Brewery, personal interview, 24 Nov. 2016, translated by the author).

Ultimately, there is still a search for actions aimed at access to suppliers, cost reduction and increasing the market. This leads to greater inter-organizational learning, as already mentioned by Dahl (2014) and Lundgren-Henriksson and Kock (2016) as the result of a process in which the organizations learn from their successes and failures, and based on them, seek to make progress by integrating their knowledge and resources to diminish uncertainty and enhance their coopetitive advantage in the market in general. At this point, some of the interviewees and those who were observed stressed that inter-organizational learning was essential for the growth of both factors and a better understanding of the market, customers, and suppliers. However, some recent studies have demonstrated that the paradox created by coopetition cannot be understood by customers; thus, it remains "hidden" from customers (Chiambaretto et al., 2016) when it refers to knowledge transfers and asymmetrical learning.

The interviewee from the Cervejaria Portoalegrense, for example, stated that "everything began because we have the same problems of production, 
raw material suppliers, taxation, and delivery. ... We saw that by sharing we could have gains together and shared processes, ... . as there aren't many suppliers in this market." This perception is shared by a partner in the Brewery Seasons, as detailed below:

We have made partnerships for purchasing inputs, such as labels and bottles since 2013, after a distribution division in 2014. I believe we are united more because of the problems than because of the bonanzas; together we solve some problems with suppliers and thus we look for new raw materials and suppliers, so we work much more in cooperation, even without having a cooperative. An interesting thing is that we do not have a bottler and we share it. Thus, we do not immobilize a big asset for ourselves and for the factories (Representative of the Brewery Seasons, personal interview, 24 Nov. 2016, translated by the authors).

In this step, the surveyed firms sought benefits generated from their collaborative agreements with rivals and with a private non-profit entity whose mission is to promote the coopetition and the development of micro and small businesses by encouraging entrepreneurship in the country. The focus at this stage was the synergy, qualification, and training of management with the objective of making the business less informal and more professional and sustainable. This is highlighted in the words of the interviewees:

We share information and relationships with producers of Porto Alegre, but also with those outside the capital and other cities of the State to exchange knowledge and resources to improve our business as a whole. ... There is the project of Sebrae that helped us a lot to integrate and become less informal and more professional. We have a group on WhatsApp and on Facebook that also assists in this exchange (Representative of the Irmãos Ferraro Microbrewery, personal interview, 24 Nov. 2016, translated by the author).

The interviewee from the Seasons Brewery (personal interview, 24 Nov. 2016, translated by the author) stated: "Yes, we share information between us (especially with older firms from the Pole, Abadessa, Ferraro Brothers, and Babel) and then Sebrae has helped us a lot with their courses and lectures". When asked about the existence of some form of learning between these organizations through cooperative interactions, for example, the accumulation of knowledge on the production and sale of special beers on the market, the interviewee from Babel (personal interview, 24 Nov. 2016, 
translated by the author) commented: "Yes, the trainings provided by Sebrae and the creation of the Brewer Pole of POA added a lot in learning and business management". This perspective is aligned with Dal-Soto and Monticelli (2017), who identified coopetition as promoting cost reduction, learning, qualification, and the differentiation of activities.

Based on these relationships, we offer the following proposition:

P1: Coopetitive relationships develop over time, according to norms and rules seeking shared interactions among the firms.

There is also a relationship of trust and learning among the breweries, according to the signatures of the interviewees from the Babel and Seasons brewery, which stated that the Gaucho Association of Microbreweries and the Beer School were the result of joint work. Since 2012, this association has generated actions for the integration, structuring, and promotion not only of the business but also of a pole that aims to promote the beer culture and business among network participants and other important segments for this inter-organizational chain. Therefore, coopetition seeks complementary resources through trust and learning, facilitating the access and acquisition of the coopetitor's valuable knowledge (Ritala \& Hurmelinna-Laukkanen, 2013).

Similarly, learning occurs through exchanging knowledge, conducting market research, and helping with market strategies.

P1.1: The accumulation of trust among competitors develops coopetitive relationships based on inter-organizational learning through exchanges with competitors.

P1.2: Intra-organizational learning develops coopetitive relationships based on exchanges with competitors.

The coopetitive relationship is due to the maximization of the results achieved by targeting efforts in the same direction, transcribed by formal or tacit agreements. For the survival of coopetitive relations, the following are important: motivation, good faith, and strategic alignment of individuals; interdependence; same cultural composition; organizational arrangements; integration and integrity between the parties (Zineldin, 2004). These agreements are based on a fragile equilibrium between players who have a common interest balanced by the power and dependency between the parties (Pellegrin-Boucher et al., 2013). Over-dependency will limit the strategic flexibility, mainly of SMEs, with larger firms forcing smaller ones to take more risks (Sulej, Stewart, \& Keogh, 2001). 
Similarly, the collected data also corroborate the third mechanism proposed by Dahl (2014), which is represented by changes in the external environment. Changes in the external environment are reported by the interviewee from Babel Brewery:

Changes started to happen from the existing dynamics in this market characterised by customers, partners, and suppliers that are the same for all in the Brewer Pole. When we start sharing information and resources, we won together and in the integration between the breweries and especially with other industries, such as hotels, restaurants, and tourism (Representative of the Babel Brewery, personal interview, 24 Nov. 2016, translated by the author).

According to the Director of the Cervejaria Portoalegrense, the largest external changes occur due to:

market demands, coopetition, and customers seeking new products with added value and quality. The customer searches for flavour and quality in the product, as well as a new experience with the product that must be even in the packing - changes that we made together because of the actions directed by the pole, ACervA, and AGM (Director of the Cervejaria Portoalegrense, personal interview, 24 Nov. 2016, translated by the author).

In this case, the coopetition allows interactions based on a paradoxical relationship, both horizontally and vertically (Bengtsson \& Kock, 2014). In addition to these mechanisms, it was noted, in the last year, that these firms had become closer to other organizations from different industries, with the aim of using the successful results from previous experiences to integrate and increase the markets through actions such as the Semana da Cerveja de Porto Alegre (Porto Alegre Beer Week), in addition to partnerships with other associations and formal institutions. For the manager of Irmãos Ferraro Microcervejaria, who spoke at the Sebrae event about management at the Brewer Pole in Porto Alegre, there is a predisposition toward this integration:

We have had an integration between our dynamics (producers) from the beginning, 10 years ago, and now we need to integrate new combinations into our distribution strategy, which we are already doing with some colleagues in the industry, like the Seasons, Babel, etc (Manager of the Irmãos Ferraro Microcervejaria, personal interview, 24 Nov. 2016, translated by the author). 
The interviewee from the Babel Brewery highlighted that:

The Association needs to be unified, as this is how we seek to join our efforts to gain space in the business of restaurants and bars and aim at a larger share where the greatest firms dominate. Our product has its differential, so we just have to be even more organized to achieve this integration (Representative of the Babel Brewery, personal interview, 24 Nov. 2016, translated by the author).

In these interviews, there is evidence that in addition to the firms that cooperate and compete, there is a deliberate coopetition strategy using a third agent (Mariani, 2007), which may be an industrial agency, for example.

Chiambaretto and Fernandez (2016) stated that co-coopetitive alliances could be combined or replaced within an association or between a portfolio of formal and/or informal alliances, seeking alignment of strategies that can reduce the risks, uncertainties, and tensions of coopetition in the market. This view is aligned with that of the respondent from Cervejaria Portoalegrense:

A greater integration and relationship with the point of sale is required, as we already do between the breweries. The interaction needs to be with the establishment and who makes the request, for example, the waiter at the restaurant needs to drink our beer and understand what the product is and to whom he must sell it. . . . Information synergy, like we have in the group, already works, but now we need to take it out of our industry as the goal is to sell more products (Representative of the Cervejaria Portoalegrense Brewery, personal interview, 24 Nov. 2016, translated by the authors).

Therefore, that analysis showed that the process of the development of a coopetition strategy is present in the inter-organizational relationships of the microbreweries in Porto Alegre. It is noteworthy, however, that the importance of cooperation and coopetition stands out in the distribution and sale of products. The findings suggest that this process plays a significant role in the challenges and successes found in this research. Nevertheless, in unexploited or innovative markets, firms seem to have no choice except to deal with a competitor to gain an advantage in the coopetition (Chiambaretto \& Fernandez, 2016).

Based on these relationships, we suggest the following proposition: 
P2: Formal institutions can promote coopetition in an industry by contributing to the establishment or formalization of a collaborative strategy in a new or relatively unexploited environment between firms that are rivals in a different environment.

It is also observed that relationships lead to the frequent sharing of contacts and information, providing a joint search for business and market opportunities through new suppliers and partners from other segments, such as hotels, bars, and restaurants. This search stimulates exchanging relationships that may or may not be successful for both network participants but generate new connections that induce a change in the network status as a whole. It increases the number of strategic options, leads to recognition by consumers of their own regional beers, and establishes new relationship strategies, highlighting coopetition not just as process but also as a context. In these terms, firms must adapt to environment changes in order to grow by forming formal institutions (Mariani \& Kylänen, 2014). Firms must align the institutions' influence with their interests. These relationships are dynamic because their goals evolve based on the previous experiences among the firms (Peng et al., 2008).

P2.1: Changes due to the external environment stimulate coopetitive relationships through formal institutions that consider the results of successful or unsuccessful previous experiences among firms.

The objectives of coopetition are to improve conditions such as size or market demand by cooperating with rival companies and to increase profits by competing with rival companies (Okura, 2007). In these cases, there are impositions or incentives from a formal institution for cooperation between firms (Mariani \& Kylänen, 2014). Induced coopetition is a transitory stage of coopetition in which cooperation is imposed on competing firms, thus creating an emerging and unintentional strategy (Kylänen \& Mariani, 2012; Mariani, 2007). Induced or forced coopetition is likely to improve performance because the firms have a higher level of efficiency as a result of the new environmental conditions (Mariani, 2007).

Following this logic, co-coopetitive relations are seen as being developed over time and as meeting the prepositions and dimensions proposed by Dahl (2014). Thus, the relationship between the actors in this network is consolidated according to the trust generated by the new interactions and learning. This integration can cause new exchanges between stakeholders, competitors, suppliers, and business partners by promoting joint cooperation 
and coopetition actions in which agents which were once rivals in the market become partners in new environments and as changes occur in the external environment. A formalization of the strategies generating collaborative results for all involved has also been observed.

To elucidate this context, Figure 6.1 summarizes the findings which best characterize the motivational mechanisms, common goals, and processes performed and observed in this study.

\section{(Figure 6.1) \\ RESULTS FOUND}

\begin{tabular}{|c|c|c|}
\hline Motivating Mechanisms & Common Goals & Processes Performed \\
\hline $\begin{array}{l}\text { Process of inter- } \\
\text {-organizational learning } \\
\text { with the accumulation of } \\
\text { trust among competitors } \\
\text { (Dahl, 2014). }\end{array}$ & $\begin{array}{l}\text { Exchange of experiences; } \\
\text { Conjoint learning; Access } \\
\text { to suppliers; Supply chain } \\
\text { integration; Cost } \\
\text { reduction. }\end{array}$ & $\begin{array}{l}\text { Foundation of the AGM; Search for } \\
\text { quality raw material; Conjoint } \\
\text { acquisitions; Product development and } \\
\text { joint actions; Founding of the Beer } \\
\text { School. }\end{array}$ \\
\hline $\begin{array}{l}\text { Learning inside the } \\
\text { organization through } \\
\text { exchanges with other } \\
\text { competitors (Dahl, 2014). }\end{array}$ & $\begin{array}{l}\text { Synergy; Information flow; } \\
\text { Qualification and training } \\
\text { of the management. }\end{array}$ & $\begin{array}{l}\text { Partnership with SEBRAE-RS and } \\
\text { creation of the POA and RS Brewer } \\
\text { Pole for training, qualification, and } \\
\text { synergy of the management, } \\
\text { relationships, and production. }\end{array}$ \\
\hline $\begin{array}{l}\text { Changes due to the } \\
\text { external environment } \\
\text { (Dahl, 2014). }\end{array}$ & $\begin{array}{l}\text { Changes in the } \\
\text { relationships; Information } \\
\text { sharing; Frequency of } \\
\text { contact; Interactions and } \\
\text { connections with other } \\
\text { segments; Market search. }\end{array}$ & $\begin{array}{l}\text { Foundation of ACervA in Rio Grande } \\
\text { do Sul; Monthly meetings with beer } \\
\text { producers from all over the State; } \\
\text { Group creation of social networks with } \\
\text { producers, suppliers, and partners from } \\
\text { other sectors (hotels, bars, and } \\
\text { restaurants). }\end{array}$ \\
\hline $\begin{array}{l}\text { Results from successful } \\
\text { or unsuccessful previous } \\
\text { experiences (Dahl, 2014). }\end{array}$ & $\begin{array}{l}\text { Conjoint actions; } \\
\text { Integration with other } \\
\text { sectors; Participative } \\
\text { processes; Market } \\
\text { expansion. }\end{array}$ & $\begin{array}{l}\text { Conjoint distribution; Partnership with } \\
\text { other public and private sectors; } \\
\text { Events; Creation of the Semana da } \\
\text { Cerveja de POA (Beer Week in POA). }\end{array}$ \\
\hline
\end{tabular}

Source: Elaborated by the authors.

Following the analysis of the coopetition case, characterized by the motivational mechanisms, common goals, and processes, the final considerations are presented. 


\section{FINAL CONSIDERATIONS}

This study aimed to establish theoretical propositions about coopetition strategies through gaining an understanding of the process of coopetitive development among small businesses in the brewery industry. A case study was carried out in a group of small businesses in the brewery cluster in Porto Alegre. To this end, the concept of coopetition is seen as a process by Bengtsson and Kock (2014), who showed that one of the fields of study that has not been adequately explored is the dynamics and development of the coopetitive strategy. In this sense, the proposal of Dahl (2014) was used to understand this dynamic in the development of the coopetition strategy through four mechanisms (inter-organizational learning; intra-organizational learning; external changes; successful or unsuccessful results from previous experiences).

Based on the proposal of Dahl (2014), the study aimed to observe if the proposed mechanisms arose in a practical case study. To this end, the study showed how the goals and purposes of coopetition occurred and developed between the small breweries of Porto Alegre, relating them to the propositions of Dahl (2014) and formulating new propositions. Therefore, Dahl's proposal can be validated and improved. Given the range of results, it is considered that the major contribution of this study was to put into practice empirical research based on the theoretical proposal of Dahl (2014), using as the context the small businesses of an emerging industry. Thus, the triangulation of qualitative methods was used to understand how this evolution of the coopetitive strategy occurred among small-sized firms from a specific business pole within an evolving market.

The results of the empirical study showed that microbreweries in the cluster of Porto Alegre are developing a strategic process of coopetition through greater sharing of resources, information, interactions, learning, and inter-organizational and intra-organizational knowledge. One of the strengths of coopetition is highlighted: it makes it possible to address the changes arising from the external environment, generating coopetitive success in dealing with the market and the other players in the beer sector. In addition, the reports and evidence of the research show synergy between the mechanisms and common goals found, thus demonstrating the dynamic of these small businesses, which are re-shaping the regional economy through strategies based on coopetition.

There have been few attempts to understand the dynamics of coopetition that simultaneously consider the external and internal environments. Rather, coopetition has been analyzed separately and only through the 
chosen unit of analysis. Consequently, an equation that aims to understand the coopetitive relationships should further the theory through propositions. Therefore, SMEs are an appropriate object of study in this context because of their need to engage in coopetition strategies to improve their coopetition. In addition, the theoretical propositions presented here appear to be a promising direction for future attempts to investigate coopetition within an integrated analytical framework.

Based on these firms' relationship, we presented the first proposition stating that the coopetitive relationships develop over time, according to norms and rules aimed at shared interactions by the firms. Once there is also a relationship of trust and learning among the breweries, we propose a theoretical advancement of Dahl's (2014) propositions, whereby we consider that the accumulation of trust among competitors develops coopetitive relationships based on inter-organizational learning through exchanges with competitors. Simultaneously, we consider that intra-organizational learning develops coopetitive relationships based on exchanges with competitors.

Based on the firms' coopetition, we presented the second proposition stating that formal institutions can promote coopetition in an industry by contributing to the establishment or formalisation of a collaborative strategy in a new or relatively unexploited environment between firms that are rivals in a different environment. Considering that relationships lead to the frequent sharing of contacts and information, we also indicate that changes due to the external environment stimulate coopetitive relationships through formal institutions that consider the results of successful or unsuccessful previous experiences among the firms.

Although the case has been discussed in light of the theory, this study has limitations that should be considered and suggestions for future research. As a limiting factor, there was a limited number of participants during data collection, which should be expanded for a better generalization of the study, especially using quantitative methods. Furthermore, considering the dynamism of coopetition, the research portrays a static moment. Future studies could follow the evolution of the coopetition process of the microbreweries, which could change according to the development and maturation of an inter-organizational relationship (Dahl, 2014), and the intensity of the coopetition and cooperation movements should be considered (Dal-Soto \& Monticelli, 2017). An analysis of the network governance is also suggested to gain a better understanding of the coopetition process. Finally, a consideration of the influences of the organizational field and the institutional influences field is suggested, because they are rarely associated with the theoretical views of coopetition and institutions. 


\section{O PROCESSO DE ESTRATÉGIA COOPETITIVA: UM ESTUDO DE CASO DE MICROCERVEJARIAS EM PORTO ALEGRE}

\section{RESUMO}

Objetivo: O estudo apresenta uma experiência procedural com sua dinâmica e complexidade realizada por pequenas microcervejarias em um cluster em Porto Alegre, Brasil. Portanto, o objetivo deste artigo é estabelecer proposições teóricas sobre estratégias de coopetição nesse contexto. Originalidade/relevância: Uma das lacunas nos estudos organizacionais é compreender como ocorre o processo de desenvolvimento de novas estratégias dinâmicas. Coopetição é considerada um processo que envolve restritas estratégias de competição e cooperação simultâneas entre firmas, em diferentes áreas e níveis de interação.

Principais aspectos metodológicos: Uma pesquisa qualitativa e exploratória foi conduzida, usando triangulação de dados e múltiplos métodos. O estudo de caso foi adotado para obter uma análise em profundidade do fenômeno com coleta de dados secundários, observação participante e entrevistas semiestruturadas.

Síntese dos principais resultados: Os resultados demonstraram que microcervejarias estão desenvolvendo um processo estratégico de coopetição por meio de um maior compartilhamento de recursos, informação, interações, aprendizagem e conhecimento interorganizacional e intraorganizacional, principalmente nas etapas de distribuição e vendas. Os relatos e evidências da pesquisa demonstraram uma sinergia entre os mecanismos e objetivos comuns encontrados, demonstrando a dinâmica desses pequenos negócios.

\section{PALAVRAS-CHAVE}

Coopetição. Estratégia. Aprendizagem. Processos. Microcervejaria. 


\section{REFERENCES}

Associação dos cervejeiros artesanais do Rio Grande do Sul. (2016). Histórico. Retrieved from http://www.acervagaucha.com.br/associacao/ historico

Associação Gaúcha de Microcervejarias. (2016). Posts. Retrieved from https://www.facebook.com/agm.org.rs

Bardin, L. (2011). Análise de conteúdo. São Paulo: Edições 70.

Baumard, P. (2008). Learning strategies in coopetitive environments. In F. Le Roy \& S. Yami, Coopetition: Winning strategy for the XXIst century. Northampton, MA: Edward Edgar Publishing. pp. 125-145.

Beer Art O Portal da Cerveja. (2016). News. Retrieved from http://revista beerart.com.

Bengtsson, M., Eriksson, J., \& Wincent, J. (2010). Co-opetition dynamics: An outline for further inquiry. International Business Journal, 20(2), 194-214. doi:10.1108/10595421011029893

Bengtsson, M., \& Johansson, M. (2012). Managing coopetition to create opportunities for small firms. International Small Business Journal, 32 (4), 401-427. doi:10.1111/1467-8551.12213

Bengtsson, M., \& Kock, S. (1999). Cooperation and coopetition in relationships between competitors in business networks. Journal of Business E Industrial Marketing, 14(3), 178-194. doi:10.1108/08858629910272184

Bengtsson, M., \& Kock, S. (2000). Coopetition in business networks to cooperate and compete simultaneously. Industrial Marketing Management, 29(5), 411-426. doi:10.1016/S0019-8501(99)00067-X

Bengtsson, M., \& Kock, S. (2014). Coopetition-Quo vadis? Past accomplishments and future challenges. Industrial Marketing Management, 43 (2), 180-188. doi:10.1016/j.indmarman.2014.02

Bengtsson, M., Kock, S., Lundgren-Henriksson, E. L., \& Näsholm, M. H. (2016). Coopetition research in theory and practice: Growing new theoretical, empirical, and methodological domains. Industrial Marketing Management, 57, 4-11. doi:10.1016/j.indmarman.2016.05.002

Bengtsson, M., \& Raza-Ullah, T. (2016). A systematic review of research on coopetition: Toward a multilevel understanding. Industrial Marketing Management, 57, 23-39. doi:10.1016/j.indmarman.2016.05.003 
Brandenburger, A. M., \& Nalebuff, B. J. (1995). The right game: Use game theory to shape strategy. Harvard Business Review, 73(4), 57-71.

Brandenburger, A. M., \& Nalebuff, B. J. (1996). Co-opetition. São Paulo: Rocco.

Bouncken, R. B., Gast, J., Kraus, S., \& Bogers, M. (2015). Coopetition: A systematic review, synthesis, and future research directions. Review of Managerial Science, 9(3), 577-601. doi:10.1007/s11846-015-0168-6

Chen, M. J. (2008). Reconceptualizing the coopetition-cooperation relationship: A transparadox perspective. Journal of Management Inquiry, 17(4), 288-304. doi:10.1177/1056492607312577

Chiambaretto, P. (2015). Resource dependence and power-balancing operations in alliances: The role of market redefinition strategies. Management, 18(3), 205-233. doi:10.1016/j.indmarman.2016.05.005

Chiambaretto, P., \& Fernandez, A. S. (2016). The evolution of coopetitive and collaborative alliances in an alliance portfolio: The Air France case. Industrial Marketing Management, 57, 75-85. doi:10.1016/j.indmarman. 2016.05.005

Chiambaretto, P., Gurău, C., \& Le Roy, F. (2016). Coopetitive branding: Definition, typology, benefits and risks. Industrial Marketing Management, 57, 86-96. doi:10.1016/j.indmarman.2016.05.009

Chiambaretto, P., Le Roy, F, Mira, B., \& Robert, M. (2018). Better, faster, stronger: The impact of market-oriented coopetition on product commercial performance.M@n@gement, 21(1),574-610.

Choi, P. (2005). The nature of co-opetition: Literature review and propositions. Proceeding of the Educators' Conference, USA, 16, 105-106.

Choi, P., Garcia, R., \& Friedrich, C. (2010). The drivers for collective horizontal coopetition: A case study of screwcap initiatives in the international wine industry. International Journal of Strategic Business Alliances, 1(3), 271-290. doi: 10.1016/j.scaman.2008.03.005

Dahl, J. (2014). Conceptualizing coopetition as a process: An outline of change in cooperative and coopetitive interactions. Industrial Marketing Management, 43(2), 272-279. doi:10.1016/j.indmarman.2013.12.002

Dal-Soto, F., \& Monticelli, J. M. (2017). Coopetition strategies in the Brazilian higher education. Revista de Administração de Empresas, 57(1), 65-78. doi:10.1590/s0034-759020170106 
Dussauge, P., Garrete, B., \& Mitchell, W. (2000). Learning from competing partners: Outcomes and durations of scale and link alliances in Europe, North America and Asia. Strategic Management Journal, 21, 99-126. doi:10.1002/(SICI) 1097-0266(200002)21:2\%3C99::AID-SMJ80\%3 E3.0.CO;2-G

Escola da Cerveja. (2016). Home. Retrieved from https://site.escoladacerveja. com.br.

Flick, U. (2014). An introduction to qualitative research. London: Sage.

Gnyawali, D. R., \& Madhavan, R. (2001). Cooperative networks and coopetitive dynamics: A structural embeddedness perspective. Academy of Management Review, 26(3), 431-445. doi:10.2307/259186

Gnyawali, D. R., He, J., \& Madhavan, R. (2006). Impact of co-opetition on firm coopetitive behaviour: An empirical examination. Journal of Management, 32 (4), 507-530. doi:10.1177/0149206305284550

Gnyawali, D. R., He, J., \& Madhavan, R. (2008). Co-opetition: Promises and challenges. In: C. Wankel (Ed.), $21^{\text {st }}$ century management: A reference handbook (pp. 386-398). London: Sage Publications.

Gnyawali, D. R., \& Park, R. (2009). Co-opetition and technological innovation in small and medium-sized enterprises: A multilevel conceptual model. Journal of Small Business Management, 47(3), 308-330. doi:10.1111/ j.1540-627X.2009.00273.x

Gnyawali, D. R., \& Park, R. (2011). Co-opetition between giants: Collaboration with competitors for technological innovation. Research Policy, 40, 650-663. doi:10.1016/j.respol.2011.01.009

Google Maps. (2017). Adapted location map of the breweries described in this study. Retrieved from https://www.google.com.br/maps/search/ cervejarias+porto+alegre/@-29.9778273,-51.1769203,16.25z

Gulati, R., Nohria, N., \& Zaheer, A. (2000). Strategic networks. Strategic Management Journal, 21 (3), 203-215. doi:10.1002/(SICI) 1097-0266(2000 03)21:3<203::AID-SMJ102>3.0.CO;2-K

Hamel, G. (1991). Coopetition for competence and inter-partner learning within international strategic alliances. Strategic Management Journal, 12, 83-103. doi:10.1002/smj.4250120908

Huang, H.-C., \& Chu, W. (2015). Antecedents and consequences of co-opetition strategies in small and medium-sized accounting agencies. Journal of Management $\mathcal{E}$ Organization, 21 (6), 812-834. doi:10.1017/jmo. 2014.82 
Hung, S.-W., \& Chang, C.-C. (2012). A co-opetition perspective of technology alliance governance modes. Technology Analysis \& Strategic Management, 24(7), 679-696. doi:10.1080/09537325.201 2.705120

Kanter, R. M. (1994). Collaborative advantage: The art of alliances. Harvard Business Review, 72 (4), 96-108. doi:10.1225/94405

Kylänen, M., \& Mariani, M. M. (2012). Unpacking the temporal dimension of coopetition in tourism destinations: Evidence from Finnish and Italian theme parks. Anatolia: An International Journal of Tourism and Hospitality Research, 23(1), 61-74. doi:10.1080/13032917.2011.653632

Lado, A. A., Boyd, N. G., \& Hanlon, S. C. (1997). Coopetition, cooperation, and the search for economic rents: a syncretic model. Academy of Management Review, 2(1), 110-141. doi:10.2307/259226

Le Roy, F., Fernandez, A.-S., \& Chiambaretto, P. (2017). Managing coopetition in knowledge-based industries. In: S. Sindakis \& P. Theodorou (Eds.), Global opportunities for entrepreneurial growth: Coopetition and knowledge dynamics within and across firms; Advanced strategies in entrepreneurship, education and ecology (pp. 187-198). Bingley: Emerald Publishing Limited.

Lundgren-Henriksson, E. L., \& Kock, S. (2016). A sensemaking perspective on coopetition. Industrial Marketing Management, 57, 97-108. doi:10.1016/j. indmarman.2016.05.007

Luo, Y. (2005). Toward coopetition within a multinational enterprise: A perspective from foreign subsidiaries. Journal of World Business, 40(1), 71-90. doi:10.1016/j.jwb.2004.10.006

Luo, Y. (2007). From foreign investors to strategic insiders: Shifting parameters, prescriptions and paradigms for MNC's in China. Journal of World Business, 42 (1), 14-36. doi: 10.1509/jmkg.70.2.67

Luo, Y., Slotegraaf, R. J., \& Pan, X. (2006). Cross-functional coopetition: The simultaneous role of cooperation and coopetition within firms. Journal of Marketing, 70, 67-81.

Mariani, M. M. (2007). Coopetition as an emergent strategy: Empirical evidence from an Italian consortium of opera houses. International Studies of Management and Organization, 37(2), 97-126. doi:10.2753/imo00208825370205

Mariani, M. M., \& Kylänen, M. (2014). The relevance of public-private partnerships in coopetition: Empirical evidence from the tourism sector. International Journal of Business Environment, 6(1), 106-125. doi:10.1016/j. indmarman.2015.11.015 
Malhotra, N. K. (2017). Marketing research: An applied orientation ( $6^{\text {th }}$ ed.). New Jersey: Prentice Hall, 2010.

Nash, J. (1950). The bargaining problem. Econometrica, 18(2), 155-162. doi:10.2307/1907266

Okura, M. (2007). Coopetitive strategies of Japanese insurance firms. International Studies of Management \& Organisation, 37(2), 53-69. doi:10.2753/ IMO0020-8825370203

Oliver, A. L. (2004). On the duality of coopetition and collaboration: Network-based knowledge relations in the biotechnology industry. Scandinavian Journal of Management, 20(1), 151-171. doi:10.1016/j.scaman. 2004.06.002

Padula, G., \& Dagnino, G. B. (2007). Untangling the rise of coopetition: The intrusion of coopetition in a cooperative game structure. International Studies of Management \& Organization, 37(2), 32-52. doi:10.1287/orsc.7.4.42

Pellegrin-Boucher, E., Le Roy, F., \& Gurău, C. (2013). Coopetitive strategies in the ICT sector: Typology and stability. Technology Analysis E Strategic Management, 25(1), 71-98. doi:10.1080/09537325.2012.751011

Peng, M. W., Wang, D., \& Jiang, Y. (2008). An institution-based view of international business strategy: A focus on emerging economies. Journal of International Business Studies, 39(8), 920-936. doi:10.1057/palgrave. jibs. 8400377

Raza-Ullah, T., Bengtsson, M., \& Kock, S. (2014). The coopetition paradox and tension in coopetition at multiple levels. Industrial Marketing Management, 43(2), 189-198. doi:10.1016/j.indmarman.2013.11.001

Ritala, P. (2012). Coopetition strategy: When is it successful? Empirical evidence on innovation and market performance. British Journal of Management, 23(3), 307-324. doi:10.1111/j.1467-8551.2011.00741.x

Ritala, P., \& Hurmelinna-Laukkanen, P. (2009). What's in it for me? Creating and appropriating value in innovation-related coopetition. Technovation, 29, 819-828. doi:10.1016/j. technovation.2009.07.002

Ritala, P., \& Hurmelinna-Laukkanen, P. (2013). Incremental and radical innovation in coopetition: The role of absorptive capacity and appropriability. Journal of Product Innovation Management, 30(1), 154-169. doi:10.1111/j.1540-5885.2012.00956.x

Roy, P., \& Yami, S. (2009). Managing strategic innovation through coopetition. International Journal of Entrepreneurship and Small Business, 8(1), 61-73. doi:10.1504/IJESB.2009.024105 
Semana da Cerveja POA. (2016). Sobre a semana. Retrieved from http:// www.semanadacerveja.com/

Serviço Brasileiro de Apoio às Micro e Pequenas Empresas. (2017). Microcervejarias ganham espaço no mercado nacional. Retrieved from https:// sebrae.com.br/sites/PortalSebrae/artigos/microcervejarias-ganhamespaco-no-mercado-nacional,fbe9be300704e410VgnVCM1000003b7401 OaRCRDm

Stefenon, R. (2012). Vantagens competitivas sustentáveis na indústria cervejeira: O caso das cervejas especiais. Revista Capital Científico, 10(1), $1-16$.

Strauss, A., \& Corbin, J. (1990). Basics of qualitative research: Grounded theory procedures and techniques. Newbury Park, CA: Sage.

Sulej, J. C., Stewart, V., \& Keogh, W. (2001). Taking risk in joint ventures: Whose throw of the dice? Strategic Change, 10(5), 285-295. doi:10.1002/ jsc. 546

Sun, G., Wu, Y., Liu, S., Peng, T-Q., Zhu, J. H., \& Liang, R. (2012). EvoRiver: Visual analysis of topic coopetition on social media. IEEE Transactions on Visualization and Computer Graphics, 20(12), 1753-1762. doi:10.1109/ TVCG.2014.2346919

Tidström, A., \& Hagberg-Andersson, Å. (2012). Critical events in time and space when cooperation turns into coopetition in business relationships. Industrial Marketing Management, 41 (2), 333-343. doi:10.1016/j.indmarman. 2012.01.005

Tidström, A., \& Rajala, A. (2016). Coopetition strategy as interrelated praxis and practices on multiple levels. Industrial Marketing Management, 58, 35-44. doi:10.1016/j.indmarman.2016.05.013

Yin, R. (2009). Case study research: Design and methods. Thousand Oaks, CA: Sage.

Zhao, Z., Renard, D., Elmoukhliss, M., \& Balague, C. (2006). What affects creative performance in idea co-creation: Competitive, cooperative or coopetitive climate? International Journal of Innovation Management, 20(4). doi:10.1142/S1363919616400028

Zineldin, M. (2004). Co-opetition: The organization of the future. Marketing Intelligence \& Planning, 22 (7), 780-789. doi:10.1108/02634500410568600 


\section{AUTHOR NOTES}

Jefferson M. Monticelli, Business and Management Department, Universidade do Vale do Rio dos Sinos (Unisinos); Alexandre B. da Silveira, Business and Management Department, Pontifícia Universidade Católica do Rio Grande do Sul (PUC-RS); Luciana M. da Silva, Business and Management Department, Universidade do Vale do Rio dos Sinos (Unisinos).

Jefferson M. Monticelli is now an Assistant Professor of Administration at Centro Universitário La Salle (Unilasalle); Alexandre B. da Silveira is now an Assistant Professor of Administration at Centro Universitário Ritter dos Reis (UniRitter), and Luciana M. da Silva is now an Assistant Professor and Head of Executive Programs at Business and Management Department at Universidade do Vale do Rio dos Sinos (Unisinos).

Correspondence concerning this article should be addressed to Jefferson M. Monticelli, Avenida Vítor Barreto, 2288, Centro, Canoas, Rio Grande do Sul, Brazil, CEP 92010-000.

E-mail: jefferson.monticelli@unilasalle.edu.br

\section{EDITORIAL BOARD}

Editor-in-chief

Silvio Popadiuk

Associated Editor

Rafael Barreiros Porto

(iD) https://orcid.org/0000-0003-2210-7098

Technical Support

Vitória Batista Santos Silva

\section{EDITORIAL PRODUCTION}

Publishing Coordination

Irina Migliari

Language Editor

Daniel Leão

Editorial Trainee

Maria Luiza Vanz

Layout Designer

Emap

Copyeditor

Irina Migliari

Graphic Designer

Libro 